\title{
Fate of organic carbon added as diatom cells to oxic and anoxic marine sediment microcosms
}

\author{
Frede Østergaard Andersen* \\ Institute of Biology, Odense University, Campusvej 55, DK-5230 Odense M, Denmark
}

\begin{abstract}
Live Skeletonema costatum (diatom) cells labeled with ${ }^{14} \mathrm{C}$ were added to the sediment surface in 10 cores containing intertidal sediment from Saanich Inlet, Vancouver Island, Canada. The water overlying the sediment in 5 cores was sparged with atmospheric air, whereas the other 5 cores were sparged with $\mathrm{N}_{2}$. Release of ${ }^{14} \mathrm{CO}_{2}$ started immediately in the oxic cores, reaching a maximum at Days 3 to 4 , whereas release in the anoxic cores was slower with a maximum after 6 to $9 \mathrm{~d}$. DO ${ }^{14} \mathrm{C}$ (dissolved organic carbon) release also exhibited high rates initially, but with the highest release in the anoxic cores. Degradation to ${ }^{14} \mathrm{CO}_{2}$ and $\mathrm{DO}^{14} \mathrm{C}$ could be described by 2 successive exponential decays representing 2 decomposable fractions. After $80 \mathrm{~d}, 58$ and $42 \%$ of the added label had been released as ${ }^{14} \mathrm{CO}_{2}$, and 2 and $13 \%$ were released as $\mathrm{DO}^{14} \mathrm{C}$ in the oxic and anoxic cores, respectively. The porewater contained only small amounts of ${ }^{14} \mathrm{CO}_{2}$ and $\mathrm{DO}^{14} \mathrm{C}$. However, oxic cores showed the lowest concentrations, indicating faunally enhanced solute fluxes in these cores. Between 31 and $37 \%$ of the added label remained as $\mathrm{PO}^{14} \mathrm{C}$ (particulate organic carbon) in the sediment after $80 \mathrm{~d}$. Similar amounts of dissolved carbon $\left({ }^{14} \mathrm{CO}_{2}+\mathrm{DO}^{14} \mathrm{C}\right)$ were lost from the added algal POC under oxic and anoxic conditions, but the larger amounts of $\mathrm{DO}^{14} \mathrm{C}$ released from the sediment in the anoxic cores indicated a slower anaerobic mineralization of $\mathrm{DO}^{14} \mathrm{C}$.
\end{abstract}

KEY WORDS: Decomposition · Mineralization - Algae $\cdot$ Carbon dioxide

\section{INTRODUCTION}

Holland (1990) investigated the hypothesis that organic carbon is buried in marine sediments as a function of the $\mathrm{O}_{2}$ concentration in the bottom water. The idea was that with more $\mathrm{O}_{2}$ in the water carbon is oxidized, and with less $\mathrm{O}_{2}$ in the water carbon is buried. However, the analysis by Holland (1990), based on a large number of separate studies, showed that burial of carbon seemed independent of $\mathrm{O}_{2}$ in the bottom water. Canfield (1989) found that carbon oxidation rates were similar in oxic and anoxic sediments, but that only small reductions in organic carbon decomposition rates may lead to an enhanced carbon preservation in anoxic sediments. Westrich \& Berner (1984) studied the decomposition of organic matter in

•E-mail: foa@biology.ou.dk marine sediments and concluded that differences between oxic and anoxic decomposition were largely illusory, although rate constants were lowest for anoxic conditions.

A number of experimental studies also compared aerobic and anaerobic decomposition. Thus, Foree \& McCarty (1970), Otsuki \& Hanya (1972) and Fallon \& Brock (1979) found that similar amounts were lost from suspended particulate algal matter under aerobic and anaerobic conditions. Microcosm studies by Kristensen \& Blackburn (1987) and Hansen \& Blackburn (1992) showed that the mineralization of particulate organic carbon (POC) was even higher (1.5 to 2.1 times) in anoxic than in oxic marine sediment. Hansen \& Blackburn (1991) enriched sediment microcosms with macroalgal material and found that the loss of POC from the sediment was the same under oxic and anoxic conditions. They found, however, a significant difference between the 2 systems, namely, that the 
release of dissolved organic nitrogen was higher from anoxic cores than from oxic cores. This is in agreement with the study on decomposition of suspended algae by Otsuki \& Hanya (1972). Other studies have shown that the release of dissolved organic carbon (DOC) from sediments with an oxic surface layer is insignificant, although anaerobic decomposition quantitatively was important for the overall benthic metabolism in these sediments (Andersen \& Hargrave 1984, Kepkay \& Andersen 1985, Andersen \& Kristensen 1988, 1992).

The purpose of the present study was to compare $\mathrm{PO}^{14} \mathrm{C}$ loss rates and differences in mineralization under oxic and anoxic conditions in a marine intertidal sediment. The fate of organic carbon of the diatom Skeletonema costatum was followed by adding ${ }^{14} \mathrm{C}$ labeled cells to oxic and anoxic marine sediment microcosms. The use of labeled organic matter made it possible to make a complete budget, including losses of dissolved carbon both to overlying water and to porewater, and to measure remaining $\mathrm{PO}^{14} \mathrm{C}$ in the sediment.

\section{MATERIALS AND METHODS}

Cores of sandy intertidal sediment were sampled on 1 October 1990, in Patricia Bay in Saanich Inlet, Vancouver Island, Canada. Samples were taken in $40 \mathrm{~cm}$ long Plexiglas corers (inner diameter $5.2 \mathrm{~cm}$ ) at about mean low water level. In the laboratory the cores were maintained under the following experimental conditions: $15^{\circ} \mathrm{C}$, continuous darkness, and covered with seawater from the sampling site $(33 \%)$. The macrofauna was dominated by polychaetes of the families Capitellidae and Opheliidae. After the experiment the 5 oxic cores contained a total of 39 small ( 4 to $12 \mathrm{~mm}$ ) worms. Two of the oxic cores also contained a small ( 3 and $5 \mathrm{~mm}$ ) basket cockle Clinocardium nuttallii (Conrad). No live fauna was found in the anoxic cores after the experiment.

Measurements of sediment $\mathrm{O}_{2}$ uptake were made 3 times to check that total community metabolism was similar in the cores before the addition of labeled algae. $\mathrm{O}_{2}$ uptake measurements were based on initial and final samples (after ca $4 \mathrm{~h}$ ). Determination of $\mathrm{O}_{2}$ was made using the Winkler technique (Parsons et al. 1984). During incubation, the cores were closed with a magnetic stirrer that fitted into the corer leaving no headspace. The mean of 3 measurements on all cores was 1.02 (SE 0.09) $\mathrm{mmol} \mathrm{O}_{2} \mathrm{~m}^{-2} \mathrm{~h}^{-1}$ and there was no significant difference between the cores subsequently placed in the oxic and anoxic groups.

The diatom Skeletonema costatum L., originally isolated from Saanich Inlet, was cultivated in F/20 medium (Guillard \& Ryther 1962). Diatoms dominated the sedimentation in Saanich Inlet from April to September, and $S$. costatum was an important species among the diatoms (Sancetta \& Calvert 1988). The final volume of the culture was $4 \mathrm{l}$. The bacteria-free culture was labeled 6 times with $10 \mu \mathrm{Ci} \mathrm{H}^{14} \mathrm{CO}_{3}{ }^{-}$(New England Nuclear, Boston, MA, USA, $10.0 \mu \mathrm{Ci} 100 \mu^{-1}$ ) added at approximately $1 \mathrm{~d}$ intervals during the $7 \mathrm{~d}$ culture period. Immediately before addition of algae to the cores, the culture was continuously centrifuged at $3015 \times g$. The algal cells were then washed with unlabeled seawater and recentrifuged; this procedure was carried out twice to remove the labeled inorganic carbon. The algae were then suspended in $170 \mathrm{ml}$ filtered (Gelman $0.45 \mu \mathrm{m}$ ) unlabeled seawater Ten $\mathrm{ml}$ of the suspension was gently added to the sediment surface in each core without resuspending the sediment. Three aliquots of the suspension were analyzed for content of ${ }^{14} \mathrm{C}$. The particulate matter of the samples was collected on a membrane filter (Gelman $0.45 \mu \mathrm{m}$ ). The filters were flushed with $1 \mathrm{ml}$ seawater and digested in tissue solubilizer (NCS, Amersham Oakville, Ontario, Canada) overnight. The filtrate was acidified, purged with air for $20 \mathrm{~min}$, and the released free ${ }^{14} \mathrm{CO}_{2}$ was bubbled through $4 \mathrm{ml}$ phenethylamine/toluene/methanol (2/1/1) in a trap consisting of a vial with a bubbling tube mounted in the stopper (Andersen \& Kristensen 1992). The tube was flushed with $1 \mathrm{ml}$ of phenethylamine solution after purging. The radiolabel contained in acid stable organic matter was measured on the acidified samples. After addition of scintillation fluor (Formula-963, DuPont Toronto, Ontario), the radioactivity of all samples was determined by liquid scintillation counting (Beckman 9000). To each core, $846487 \mathrm{dpm}$ of ${ }^{14} \mathrm{C}$ (SE $1.83 \%$ ) was added, of which $87.2 \%$ was labeled particulate organic carbon $\left(\mathrm{PO}^{14} \mathrm{C}\right), 11.5 \%$ was dissolved organic carbon (DO ${ }^{14} \mathrm{C}$ ), and $1.3 \%$ was ${ }^{14} \mathrm{CO}_{2}$.

After addition of labeled algae, aerated seawater $(120 \mathrm{ml})$ was added to 5 cores and nitrogen-purged seawater was added to another 5 cores. Each sediment core was closed with a butyl rubber stopper. The overlying water in the cores was then bubbled slowly and continuously with humidified air or nitrogen to maintain either oxic or anoxic conditions. The experimental incubation system is shown on Fig. 1. The cores were incubated in a temperature-controlled cabinet at $15^{\circ} \mathrm{C}$ in darkness.

The release of labeled ${ }^{14} \mathrm{CO}_{2}$ and $\mathrm{DO}^{14} \mathrm{C}$ from the decomposing algae was followed over an $80 \mathrm{~d}$ period. The outlet gas from each core was purged through a $\mathrm{CO}_{2}$ trap consisting of a 0.6 I flask with approximately 0.51 of $0.5 \mathrm{M} \mathrm{NaOH}$. The trap collected $\mathrm{CO}_{2}$ over periods ranging from 1 to $21 \mathrm{~d}$, after which time the radioactivity of the solutions was measured and the traps were replaced. The volume of each trap was 


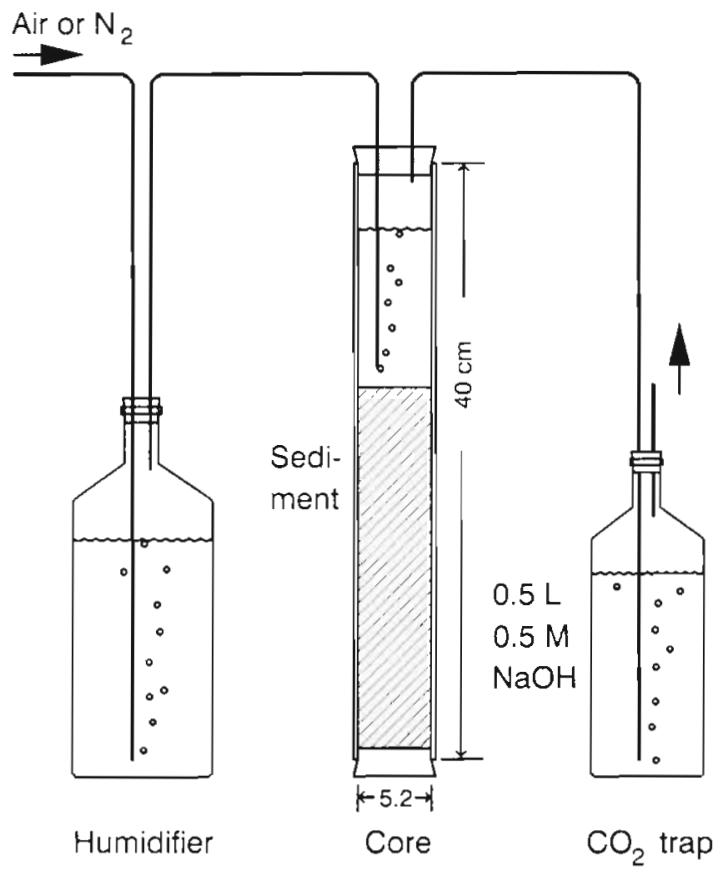

Fig. 1 Experimental incubation system. Sediment depth was $25 \mathrm{~cm}$. Ten parallel systems were used: 5 sparged with atmospheric air and 5 sparged with $\mathrm{N}_{2}$. Cores were incubated in a temperature-controlled cabinet at $15^{\circ} \mathrm{C}$

determined by weighing. The $\mathrm{CO}_{2}$ trap solutions remained alkaline over $21 \mathrm{~d}$. A similar trapping system had a $\mathrm{CO}_{2}$ trapping efficiency of $99 \%$ (Andersen \& Kristensen 1992).

After each period a $100 \mathrm{ml}$ filtered (Gelman $0.45 \mu \mathrm{m}$ ) sample of the overlying seawater in each core was taken for determination of ${ }^{14} \mathrm{CO}_{2}$ and $\mathrm{DO}^{14} \mathrm{C}$ radioactivity. The bottles with samples were connected to ${ }^{14} \mathrm{CO}_{2}$ traps and acidified as described above for algal suspensions. The total amount of inorganic carbon released over the sampling periods was calculated on the basis of the ${ }^{14} \mathrm{CO}_{2}$ concentration in the overlying water and the ${ }^{14} \mathrm{CO}_{2}$ continuously trapped from the cores. The net release of $\mathrm{DO}^{14} \mathrm{C}$ was estimated on the basis of increases in the overlying water during each period. $\mathrm{PO}^{14} \mathrm{C}$ trapped by filtering the water samples (Whatman GF/F) was also measured. Corrections were made for the $\mathrm{DO}^{14} \mathrm{C}$ and ${ }^{14} \mathrm{CO}_{2}$ initially added with the algae. The $100 \mathrm{ml}$ removed from each core at sampling was replaced with oxic or anoxic filtered seawater.

The loss of ${ }^{14} \mathrm{CO}_{2}$ and $\mathrm{DO}{ }^{14} \mathrm{C}$ from the sediment was described by the bi-exponential equation

$$
G_{\mathrm{T}}(t)=G_{01}\left[\exp \left(-k_{1} t\right)\right]+G_{02}\left[\exp \left(-k_{2} t\right)\right]+G_{N R}
$$

where $G_{T}(t)$ is the concentration of POC at time $t_{1} G_{01}$ is the initial concentration of the more reactive fraction of the organic matter, $G_{02}$ similarly represents the more slowly decomposable fraction, $G_{N R}$ is the concentration of the non-reactive organic matter that cannot be decomposed, $k_{1}$ and $k_{2}$ are the first-order decay constants for the more and the less reactive fractions, respectively, and $t$ is the decomposition time (Westrich $\&$ Berner 1984). The 2 fractions of the organic matter with different reactivity have been designated $G_{1}$ - and $\mathrm{G}_{2}$-type material. Curve fits were calculated by Fig.P (Biosoft, Ferguson, MO, USA).

At the end of the decomposition experiment (after 80 d) all cores from both groups were sliced in the following depth intervals: $0-0.5,0.5-1,1-2,2-3,3-4$, $4-5,5-7$ and $7-10 \mathrm{~cm}$. Ten $\mathrm{ml}$ of distilled water was added to weighed subsamples of the sediment slices, mixed on a vortex mixer and allowed to settle for $1 \mathrm{~h}$ in a refrigerator. Five $\mathrm{ml}$ of the diluted pore water was centrifuged for $20 \mathrm{~min}$ at $3015 \times \mathrm{g}$. Two $\mathrm{ml}$ subsamples of the supernatant were acidified for determination of ${ }^{14} \mathrm{CO}_{2}$ and $\mathrm{DO}^{14} \mathrm{C}$ as described for the algal culture above. Another $2 \mathrm{ml}$ subsample was pipetted directly into a vial and analyzed for total radioactivity. A comparison of these samples with the sum of acidified and ${ }^{14} \mathrm{CO}_{2}$ samples showed a recovery of $100.9 \%$ (SE $1.64 \%)$.

The centrifuged sediment was homogenized by stirring with a spatula and stored frozen until freeze dried. Subsamples (100 to $300 \mathrm{mg}$ ) of the dried sediment were weighed in vials, and $5 \mathrm{ml}$ distilled water and $6 \mathrm{ml}$ of Formula-963 scintillation fluor (DuPont) were added. The vials were thoroughly mixed by a vortex. mixer to ensure a uniform distribution of the sediment in the formed gel. Due to decreasing counts per gram sediment with increasing sediment weights in the vials, a correction was made for the effects of sediment. The correction factor was verified by combustion of some samples in a CHN analyzer (Hewlett-Packard 185B) combined with trapping and liquid scintillation counting of the released ${ }^{14} \mathrm{CO}_{2}$ (Andersen \& Kristensen 1992).

At the end of the experiment, redox potential (Eh) was measured in 1 core from each group by means of a platinum electrode with a calomel electrode as a reference (Hargrave 1972). Sediment porosity was determined by weighing wet and dry sediment samples (dried at $105^{\circ} \mathrm{C}$ ). Porosity varied from 0.49 at the sediment surface to 0.40 at 7 to $10 \mathrm{~cm}$ depth. Density was determined to be 2.77 by adding $10 \mathrm{ml}$ of dried particles to a $100 \mathrm{ml}$ volumetric flask containing $90 \mathrm{ml}$ distilled water and then recording the weight of the particles. The porosity and density data allowed conversions from concentrations per gram or milliliter to amounts per volume and area, which was necessary to construct a quantitative budget for the fate of the added ${ }^{14} \mathrm{C}$. The statistical comparison of data from the oxic and anoxic cores was made using a $t$-test for independent samples (SYSTAT, Evanston, IL, USA). 


\section{RESULTS}

\section{Redox conditions}

The nitrogen-sparged cores started to turn greyblack after 2 to $3 \mathrm{~d}$. Due to anoxia and formation of sulfide, macrofauna moved to the surface where they eventually died. The dead specimens were removed during the sampling. The sediment in the cores purged with air stayed light brown-grey during the experimental period. Fig. 2 shows that the Eh in the air-purged core was significantly higher than in the nitrogen-purged core at the end of the experiment. The surface of the sediment in the air-purged cores was oxidized down to $2.5 \mathrm{~cm}$ depth, whereas the sediment in the nitrogen-purged cores was reduced at all depths. The low Eh in the nitrogen-purged cores indicates that, although the nitrogen gas may have contained traces of oxygen and some oxygen may have diffused into the overlying water during sampling, oxygen consumption by the sediment was capable of creating an anoxic environment even at the sediment surface. No differences in Eh in the 2 sediment types occurred below $8 \mathrm{~cm}$ depth.

\section{Release of $\mathrm{CO}_{2}$ and $\mathrm{DOC}$ from the labeled algae}

${ }^{14} \mathrm{CO}_{2}$ release began immediately in the oxic cores, reaching a maximum at Days 3 to 4 with a release rate of $3.82 \%$ of the added label per day (Fig, 3). Decomposition started more slowly in the anoxic cores, with a maximum of $2.25 \%$ per day at Days 6 to $9 .{ }^{14} \mathrm{CO}_{2}$ release rates in both groups showed exponentially decreasing rates after the maximum. The oxic cores in general showed the highest ${ }^{14} \mathrm{CO}_{2}$ release rates $(p<$ 0.05 in 10 out of 13 measurements).

$D O{ }^{14} \mathrm{C}$ release also exhibited high rates initially (Fig. 3). However, in contrast to ${ }^{14} \mathrm{CO}_{2}$ release, maximum $\mathrm{DO}^{14} \mathrm{C}$ release was much higher in the anoxic cores $(2.29 \%$ at Days 3 to 4 ) than in the oxic cores $(0.25 \%$ at Days 3 to 4$)$. The release rates decreased with time and became very low after $3 \mathrm{wk}$. The release of $\mathrm{DO}^{14} \mathrm{C}$ in the anoxic cores was always higher than in the oxic cores. However, the difference was not statistically significant between Days 13 and 45.

Fig. 4 shows the cumulative loss of ${ }^{14} \mathrm{CO}_{2}, \mathrm{DO}^{14} \mathrm{C}$ and the sum ${ }^{14} \mathrm{CO}_{2}+\mathrm{DO}^{14} \mathrm{C}$ from the labeled algae to the overlying water during the experimental period. The inserted figures show the same data in semilogarithmic plots. These plots indicate that decomposition to ${ }^{14} \mathrm{CO}_{2}$ and $\mathrm{DO}^{14} \mathrm{C}$ can be described by 2 successive first-order (exponential) decays representing a rapidly and a slowly decomposing fraction of the organic matter. The intercepts where decomposition changed from being

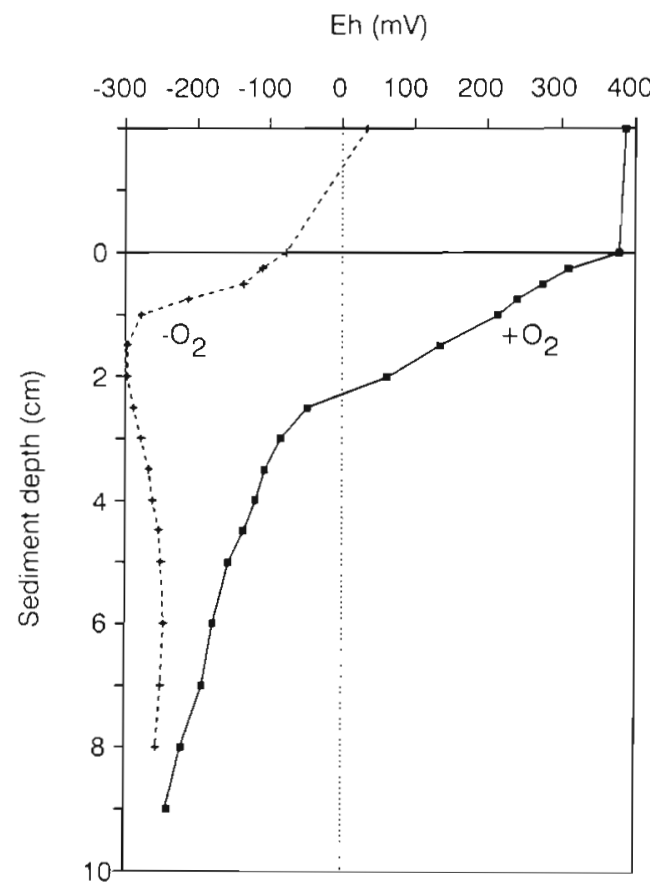

Fig. 2. Redox potential (Eh) profiles in overlying water and sediment of the oxic and anoxic cores

dominated by the more reactive fraction to being dominated by the less reactive fraction of the organic matter were at approximately 21,11 , and $20 \mathrm{~d}$ for organic matter decomposed to ${ }^{14} \mathrm{CO}_{2}, \mathrm{DO}^{14} \mathrm{C}$ and ${ }^{14} \mathrm{CO}_{2}+\mathrm{DO}^{14} \mathrm{C}$, respectively.

A bi-exponential equation (Eq. 1) was used in the present study to describe the decomposition of the different fractions of the labeled organic matter and release of ${ }^{14} \mathrm{CO}_{2}, \mathrm{DO}^{14} \mathrm{C}$ and the sum ${ }^{14} \mathrm{CO}_{2}+\mathrm{DO}^{14} \mathrm{C}$. The untransformed data on accumulated ${ }^{14} \mathrm{CO}_{2}, \mathrm{DO}^{14} \mathrm{C}$ and ${ }^{14} \mathrm{CO}_{2}+\mathrm{DO}^{14} \mathrm{C}$ release to the overlying water were used to estimate the kinetic parameters of Eq. (1) (Table 1). The curves shown on Fig. 4 are based on values estimated by Eq. (1), which all showed $r^{2}>0.98$

The decay constant $k_{1}$ for the $G_{01}$ fraction which decomposed to ${ }^{14} \mathrm{CO}_{2}$ was slightly higher for oxic than for anoxic cores (Table 1). The decomposition of the $G_{02}$ fraction to ${ }^{14} \mathrm{CO}_{2}$ was much slower in both core types than that of the $G_{01}$ fraction (12 and 72 times in the oxic and anoxic cores, respectively). The pool sizes of the 2 fractions, $G_{01}$ and $G_{02}$, that could be decomposed to ${ }^{14} \mathrm{CO}_{2}$ were equal under both oxic and anoxic conditions ( 42 to $45 \%$ of the total labeled organic matter). Thus, the remaining non-reactive fraction $G_{N R}$ was between 14 and $16 \%$ in the 2 systems.

The release of $\mathrm{DO}^{14} \mathrm{C}$ from the labeled algal material represents loss of carbon from $\mathrm{PO}^{14} \mathrm{C}$ to a dissolved state and is the first step of decomposition. The $\mathrm{DO}^{14} \mathrm{C}$ release may also be described by Eq. (1) (Table 1). The 

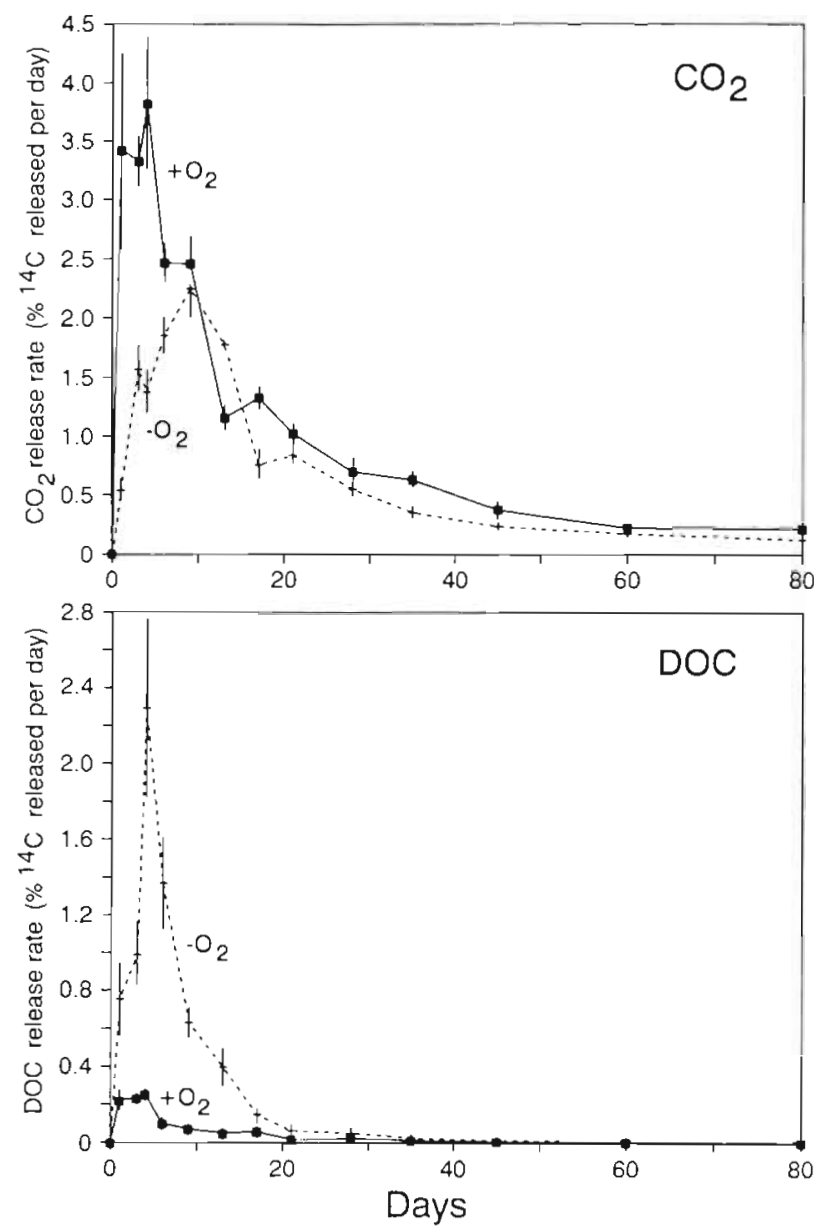

Fig. 3. Release rates of ${ }^{14} \mathrm{CO}_{2}$ and $\mathrm{DO}^{14} \mathrm{C}$ to overlying water under oxic (-) and anoxic (-......) conditions after addition of ${ }^{14} \mathrm{C}$ labeled Skeletonema costatum to the sediment surface. Means \pm SE of 5 cores are shown. Rates calculated as percentages of the added amount of label

Table 1. Rate constants $\left(k, \mathrm{yr}^{-1}\right)$ and fraction sizes $(G, \%)$ for the decomposition of labeled microalgae to ${ }^{14} \mathrm{CO}_{2}, \mathrm{DO}^{14} \mathrm{C},{ }^{14} \mathrm{CO}_{2}$ $+\mathrm{DO}^{14} \mathrm{C}$ under oxic and anoxic conditions. Values were estimated by iterated approximations by computer of the equation $G_{\mathrm{T}}(t)=G_{01}\left[\exp \left(-k_{1} t\right)\right]+G_{02}\left[\exp \left(-k_{2} t\right)\right]+G_{\mathrm{NR}}$ (see 'Materials and methods' for definitions). Sum of $G$-fractions reflects the calculated intercept of the fitted curve with the $y$-axis

\begin{tabular}{|lccccr|}
\hline & $k_{1}$ & $k_{2}$ & $G_{01}$ & $G_{02}$ & $G_{\mathrm{NR}}$ \\
\hline${ }^{14} \mathrm{CO}_{2}$ & & & & & \\
Oxic & 25.2 & 2.0 & 42.1 & 44.5 & 13.7 \\
Anoxic & 20.9 & 0.29 & 41.8 & 44.0 & 15.5 \\
DO $^{14} \mathrm{C}$ & & & & & \\
Oxic & 49.4 & 0.024 & 1.9 & 95.6 & 2.6 \\
Anoxic & 53.0 & 0.0050 & 13.7 & 74.1 & 13.0 \\
${ }^{14} \mathrm{CO}_{2}+\mathrm{DO}^{14} \mathrm{C}$ & & & & \\
Oxic & 27.2 & 3.6 & 40.9 & 35.0 & 24.4 \\
Anoxic & 28.6 & 0.69 & 50.7 & 50.7 & 1.2 \\
\hline
\end{tabular}
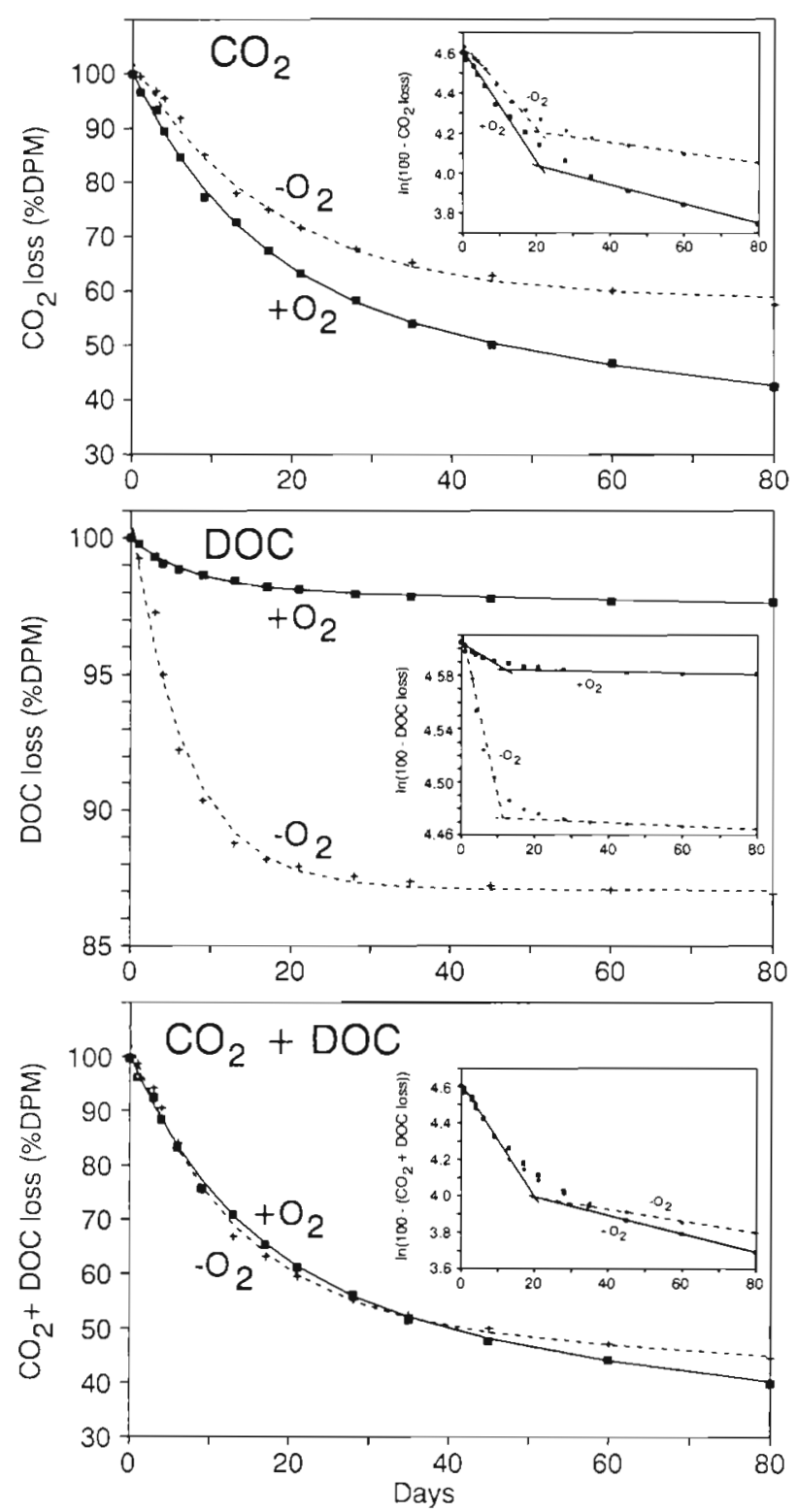

Fig. 4. Cumulative loss of ${ }^{14} \mathrm{CO}_{2}, \mathrm{DO}^{14} \mathrm{C}$ and the sum ${ }^{14} \mathrm{CO}_{2}+\mathrm{DO}^{14} \mathrm{C}$. $100 \%$ DPM indicates the amount of label initially added to the cores. Fitted curves based on a biexponential equation (Eq. 1) are shown. Inserted graphs show the same data in logarithmic plots. The lines on these graphs are linear regressions

decay constant $k_{1}$ for $\mathrm{DO}{ }^{14} \mathrm{C}$ was about twice that for ${ }^{14} \mathrm{CO}_{2}$ release in both oxic and anoxic cores. However, the estimated $G_{01}$ fractions were significantly smaller than for ${ }^{14} \mathrm{CO}_{2}$ release. The $k_{2}$-values were much lower than the $k_{1}$-values $\left(2-10 \times 10^{3}\right.$ times $)$, indicating a very low net release of $\mathrm{DO}^{14} \mathrm{C}$ from the $\mathrm{G}_{02}$ material.

Table 1 also shows the sum of ${ }^{14} \mathrm{CO}_{2}$ and $\mathrm{DO}^{14} \mathrm{C}$ release, which is the total loss of carbon from $\mathrm{PO}^{14} \mathrm{C}$. The estimated $k_{1}$ values are the same in the oxic and 


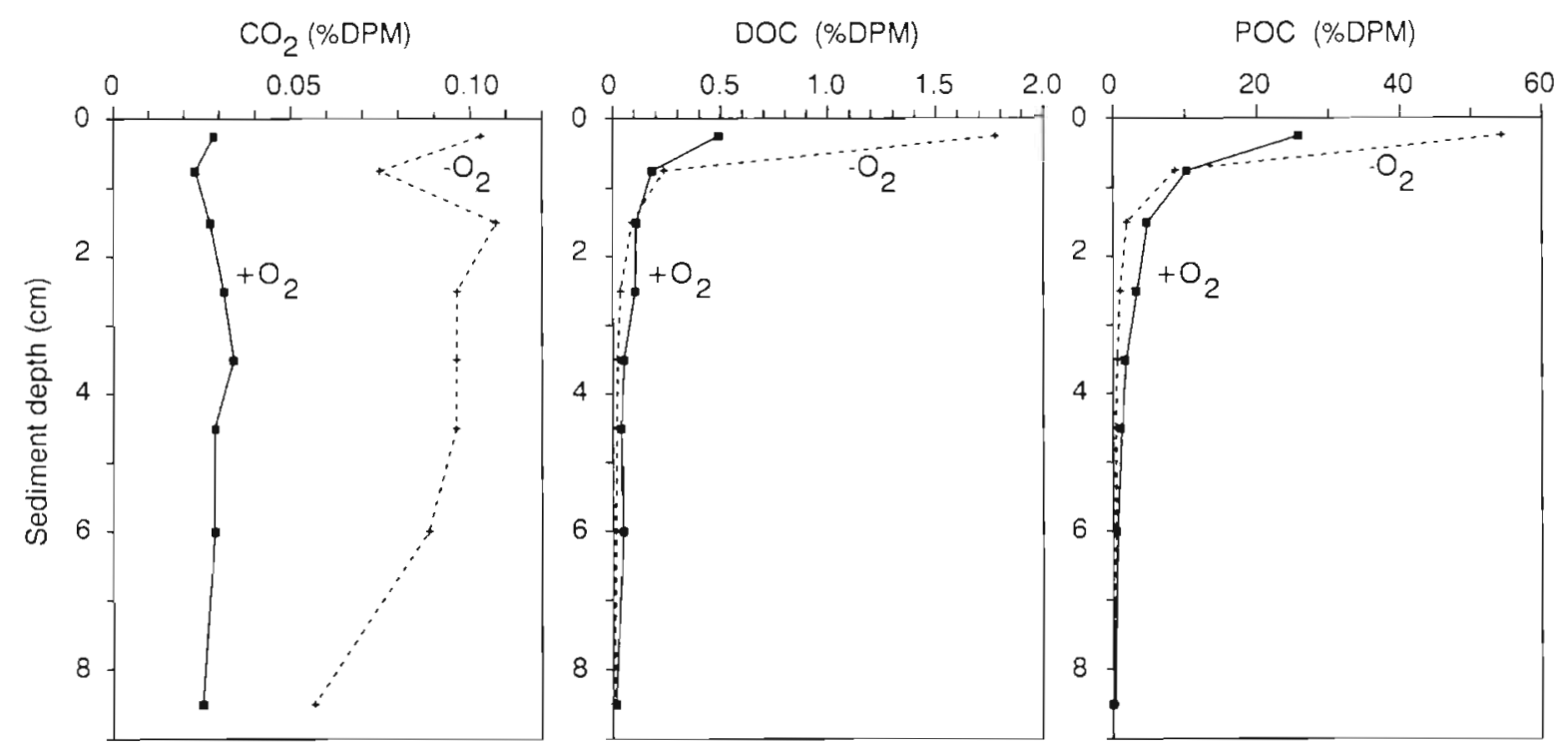

Fig. 5. Vertical profiles of ${ }^{14} \mathrm{CO}_{2}, \mathrm{DO}^{14} \mathrm{C}$ and $\mathrm{PO}^{14} \mathrm{C}$ in oxic and anoxic sediment cores after $80 \mathrm{~d}$. Mean values of 5 cores are shown. Concentrations calculated as percentage of added ${ }^{14} \mathrm{C}$

anoxic cores $\left(27.2\right.$ to $\left.28.6 \mathrm{yr}^{-1}\right)$, whereas the $k_{2}$ was 5 times higher in the oxic than in the anoxic cores. For the ${ }^{14} \mathrm{CO}_{2}$ data, the $G_{01}$ fraction was of the same size as the $G_{02}$ fraction in both types of cores.

\section{Loss and burial of $\mathrm{C}$ in the sediment}

The content of carbon in the sediment originating from the added labeled algae was measured after the experiment. The ${ }^{14} \mathrm{CO}_{2}$ concentration found in the sediment porewater of the oxic cores was almost constant with depth (Fig. 5). The anoxic cores had about 3 times higher concentration of ${ }^{14} \mathrm{CO}_{2}$ than the oxic cores in the upper $7 \mathrm{~cm}$. The concentration decreased below $7 \mathrm{~cm}$. The accumulated content of ${ }^{14} \mathrm{CO}_{2}$ in the anoxic cores, down to $10 \mathrm{~cm}$ depth, was significantly higher than in the oxic cores.

The $\mathrm{DO}^{14} \mathrm{C}$ concentration was high at the sediment surface and decreased with depth in both types of cores (Fig. 5). The anoxic cores had a greater concentration of $D \mathrm{O}^{14} \mathrm{C}$ in the upper $1 \mathrm{~cm}$ than the oxic cores ( $p=0.0068)$, whereas the oxic cores had the higher concentration below this depth ( $p=0.048)$. Below $7 \mathrm{~cm}$ the concentrations were almost the same in the 2 types of cores.

The $\mathrm{PO}^{14} \mathrm{C}$ distribution with depth was similar to that of $\mathrm{DO}^{14} \mathrm{C}$ at the end of the experiment, although the concentration of $\mathrm{PO}^{14} \mathrm{C}$ was much higher (Fig. 5). A comparison of the total amounts of remaining $P O{ }^{14} \mathrm{C}$ for 0 to $10 \mathrm{~cm}$ depth showed no significant differences between oxic and anoxic cores, whereas the amounts found in the 0.5 to $5 \mathrm{~cm}$ interval were signifi- cantly higher in the oxic than in the anoxic cores ( $\mathrm{p}=$ $0.0068)$.

The budget for the labeled carbon added via the Skeletonema costatum algae is shown in Table 2. It appears that $15.1 \%$ more ${ }^{14} \mathrm{CO}_{2}$ was released in the oxic cores than in the anoxic cores, whereas $10.8 \%$ more $\mathrm{DO}^{14} \mathrm{C}$ was released in the anoxic cores. The amount of particulate label trapped on filters was also considerably higher in the anoxic cores. In both types of cores, the content of dissolved ${ }^{14} \mathrm{C}$ compounds in the sediment porewater was negligible $(<2 \%)$ compared to the amounts released from the sediment to overlying water. The sum of ${ }^{14} \mathrm{C}$ retrieved in the various fractions

Table 2. Budget for the added ${ }^{14} \mathrm{C}$ after $80 \mathrm{~d}$ of aerobic and anaerobic decomposition. Mean values $( \pm S E), n=5$, are shown. Values in the aerobic and anaerobic columns were calculated as percentage of the ${ }^{14} \mathrm{C}$ added via the microalgae. The last column contains p-values from the t-tests indicating statistical differences between the aerobic and anaerobic cores. PW: porewater

\begin{tabular}{|lccl|}
\hline & Aerobic & Anaerobic & \multicolumn{1}{c|}{$\mathrm{p}$} \\
\hline Released ${ }^{14} \mathrm{CO}_{2}$ & $57.58(0.89)$ & $42.44(1.10)$ & 0.000016 \\
Released $\mathrm{DO}^{14} \mathrm{C}$ & $2.34(0.17)$ & $13.11(0.93)$ & 0.00037 \\
Filter $\mathrm{PO}^{14} \mathrm{C}^{2}$ & 0.70 & 3.33 & \\
$\mathrm{PW}{ }^{14} \mathrm{CO}_{2}$ & $0.28(0.012)$ & $0.83(0.065)$ & 0.000079 \\
$\mathrm{PW} \mathrm{DO}{ }^{14} \mathrm{C}$ & $0.79(0.13)$ & $1.23(0.10)$ & 0.045 \\
Sediment POC & $31.18(2.10)$ & $36.86(3.12)$ & 0.214 \\
Total & 92.87 & 97.80 & \\
& & \\
a ${ }^{14} \mathrm{C}$ retrieved on filters at sampling. Individual filters for \\
each core were not usedi hence, no SE was calculated
\end{tabular}


released from the added $\mathrm{PO}^{14} \mathrm{C}$ was identical in the oxic and anoxic cores (61.7 and $60.9 \%$, respectively). The total amount of label that could be accounted for varied between 92.9 and $97.8 \%$ of the added label (Table 2).

\section{DISCUSSION}

In various studies of decomposition, the decay rate has been measured as loss of mass or carbon from particulate organic material (e.g Foree \& McCarty 1970, Andersen \& Hargrave 1984, Westrich \& Berner 1984). The experimental design of the present study prevented direct measurements of the decrease in $\mathrm{PO}^{14} \mathrm{C}$ during the time course of the experiment. However, the budget at the end of the experiment shows that the sum of the $\mathrm{DO}^{14} \mathrm{C}+{ }^{14} \mathrm{CO}_{2}$ released to overlying water is representative of the loss from $\mathrm{PO}^{14} \mathrm{C}$, because the amounts of ${ }^{14} \mathrm{CO}_{2}$ and $\mathrm{DO}^{14} \mathrm{C}$ found in the sediment were insignificant and the retrieval of the added label was close to $100 \%$. Only $2.1 \%$ of the ${ }^{14} \mathrm{C}$ was found in dissolved compounds in the sediment and $3.3 \%$ was trapped on filters for the anoxic cores, and less for the oxic cores. The total amounts of ${ }^{14} \mathrm{CO}_{2}+\mathrm{DO}^{14} \mathrm{C}$ released to both overlying water and porewater during the experimental period were therefore almost identical under both oxic and anoxic conditions $(61.0$ and $57.6 \%$, respectively, Table 2 ). The present study thus indicates that decomposition, when defined as loss from $\mathrm{PO}^{14} \mathrm{C}$, was similar under oxic and anoxic conditions.

Although sulfate reduction, which usually is the quantitatively dominant anaerobic mineralization process (Jørgensen \& Fenchel 1974), is energetically less efficient than aerobic respiration (Claypool \& Kaplan 1974), a number of studies have reported rates for anaerobic decomposition similar to or higher than those for aerobic conditions (Foree \& McCarty 1970, Fallon \& Brock 1979, Kristensen \& Blackburn 1987. Hansen \& Blackburn 1991, 1992).

Differences in both the experimental methods and the sources of algal material make it difficult to compare the decay constants measured in the present study with those from the literature. The loss from POC in the present study was not solely an effect of microbial decomposition, but was also due to faunal decomposition of the diatoms (in oxic cores) and to initial respiration and secretion by the diatoms, which were added live to the sediment. However, Westrich \& Berner (1984) studied the decomposition of diatoms in suspensions under oxic conditions and found $k_{1}=24 \pm$ $4 \mathrm{yr}^{-1}$ and $k_{2}=1.4 \pm 0.7 \mathrm{yr}^{-1}$ for the loss from POC. These values are very close to the decay constants for loss of carbon from $\mathrm{PO}^{14} \mathrm{C}$ found in the present study $\left(k_{1}=27.2 \mathrm{yr}^{-1}, k_{2}=3.6 \mathrm{yr}^{-1}\right)$. Westrich \& Berner (1984) also provided a table of decay constants found in the literature with values for $k_{1}$ from 3 to $33 \mathrm{yr}^{-1}$ and $k_{2}$ from 0.3 to $3.2 \mathrm{yr}^{-1}$; thus, the rates obtained in the present study are at the upper end of the reported range.

Henrichs \& Doyle (1986) investigated the decomposition of radiolabeled diatoms in sediment microcosms and found decay constants of $>50 \mathrm{yr}^{-1}$ for the labile algal fraction, and of 1 to $3 \mathrm{yr}^{-1}$ for the less reactive fraction. The higher initial rates found in their study may have been caused by homogenization and freezing of the algae before the experiment. A number of studies on decomposition of dried and freeze-dried microalgae have found an initial leaching phase which may account for losses of up to $50 \%$ of the POC during the first hours to days of decomposition (e.g. Otsuki \& Hanya 1972). In the present study, where live Skeletonema costatum cells were added to the sediment, only limited amounts were leached. Freezing of the algal material used in the present study led to a release of $32 \%$ of the total labeled carbon, due to disruption of the cell walls. Andersen \& Kristensen (1992) were also unable to detect a leaching phase in a study on decomposition of live benthic microalgae. It is therefore questionable if the high leaching rates found in the literature on experimental decay of microalgae in the laboratory are valid for in situ conditions.

The maximum release rates for ${ }^{14} \mathrm{CO}_{2}$ in the anoxic cores were delayed as compared to oxic cores. The explanation for this may be that an anaerobic microbial population had to develop in the previously oxic surface layer during the lag phase. The amount of ${ }^{14} \mathrm{CO}_{2}$ released during the experimental period was $25.2 \%$ lower in the anoxic cores. Another explanation may be that some of the ${ }^{14} \mathrm{CO}_{2}$ in the oxic cores at the beginning of the experiment was released by respiration of the diatoms. Anderson et al. (1986) found that benthic mineralization (measured as $\mathrm{TCO}_{2}$ production) decreased by $60 \%$ when the $\mathrm{O}_{2}$ concentration fell below $100 \mu \mathrm{M}$. However, this decrease in $\mathrm{TCO}_{2}$ production may also have been caused by a decrease in bioturbation and faunal respiration at low $\mathrm{O}_{2}$ concentrations. This is indicated by a number of studies in which similar differences between microcosms with fauna and without fauna have been found (Andersen \& Kristensen 1988, 1992, Kristensen et al. 1992). In contrast to Anderson et al. (1986), Kristensen \& Blackburn (1987) found even higher $\mathrm{TCO}_{2}$ production under anoxic conditions than under oxic conditions.

Andersen \& Kristensen (1992) studied the decomposition of ${ }^{14} \mathrm{C}$-labeled benthic diatoms in sediment microcosms with methods and temperatures similar to those used in the present study. They found only one fraction of organic matter, which had a decay constant of 6.9 to $7.3 \mathrm{yr}^{-1}$ for ${ }^{14} \mathrm{CO}_{2}$ release. However, their study 
was terminated after only $21 \mathrm{~d}$, which may explain why only one fraction was detected. The comparable $k_{1}$ value for ${ }^{14} \mathrm{CO}_{2}$ release in the present study was 3.5 times higher. The higher rate in the present study may be due to differences in populations of heterotrophic microorganisms and fauna.

The release of $\mathrm{DO}^{14} \mathrm{C}$ from the most reactive fraction as indicated by the $k_{1}$-values was faster than the ${ }^{14} \mathrm{CO}_{2}$ release and was similar in the 2 groups. This indicates an initial leaching of soluble organic carbon from the $\mathrm{PO}^{14} \mathrm{C}$. However, the small amount of $\mathrm{DO}^{14} \mathrm{C}$ leached corresponded to the estimated small pool of labile organic matter. The release of $\mathrm{DO}^{14} \mathrm{C}$ from the more refractory matter was very slow. However, the kinetic parameters for $\mathrm{DO}^{14} \mathrm{C}$ cannot be evaluated in the same way as those for ${ }^{14} \mathrm{CO}_{2}$, because DOC can be an intermediate product between $\mathrm{POC}$ and $\mathrm{CO}_{2}$. The high $k_{1}$-values for $\mathrm{DO}^{14} \mathrm{C}$ thus indicate that the further decomposition to ${ }^{14} \mathrm{CO}_{2}$ initially is slower, which implies an accumulation of $\mathrm{DO}^{14} \mathrm{C}$. In contrast, the low $k_{2}$-values indicate a very low net accumulation of $\mathrm{DO}^{14} \mathrm{C}$ in later stages, either because there was a low production of $\mathrm{DO}^{14} \mathrm{C}$ or because the rate of further mineralization to ${ }^{14} \mathrm{CO}_{2}$ was not limiting after the necessary microbial biomass had been built up.

The actual amount of $D O^{14} \mathrm{C}$ released during the entire experimental period was 5.6 times higher in the anoxic cores than in the oxic cores. This may indicate that the anaerobic microorganisms are less efficient in utilizing the available $\mathrm{DO}^{14} \mathrm{C}$. In general, lignin is considered refractory under anaerobic conditions (Benner et al. 1984), but a slow decomposition of lignin has been observed in some studies, e.g. in the anoxic sediment of the deeper part of Saanich Inlet (Hamilton \& Hedges 1988). Reichardt (1986) studied POM-solubilizing enzymatic activity in marine sediments and found varying effects of $\mathrm{O}_{2}$ depletion and low Eh. No influence was observed on chitinase activity, while protease activity decreased under $\mathrm{O}_{2}$ depletion, but not if the samples had been homogenized. Skele. tonema costatum does not contain lignin and is mainly composed of protein (58\%), carbohydrate (33\%) and fat $(7 \%$ ) (Parsons et al. 1984). The present study does not indicate any differences in the POC to DOC step under the 2 conditions. It is therefore not likely that decreased protease activity in the anoxic cores explains the lower oxidation to ${ }^{14} \mathrm{CO}_{2}$ in the anoxic cores. Rather, this may be because, under anoxic conditions, conversion of DOC to $\mathrm{CO}_{2}$ is a multistep process and it requires a complex balanced community of microorganisms which might not have developed rapidly in the anoxic sediment.

The significant differences between oxic and anoxic cores, with respect to the distribution with depth of both ${ }^{14} \mathrm{CO}_{2}$ and $\mathrm{DO}^{14} \mathrm{C}$, are probably due to bioturba- tion caused by the benthic fauna present in the oxic cores. The fauna died in the anoxic cores; thus, the almost constant and low concentration of ${ }^{14} \mathrm{CO}_{2}$ found in the oxic cores was probably caused by faunally mediated transport to the overlying water The tendency for the fauna to diminish concentration gradients in the porewater is also reflected in the $\mathrm{DO}^{14} \mathrm{C}$ profiles. The $\mathrm{DO}^{14} \mathrm{C}$ concentration is lower at the sediment surface, but is higher deeper in the sediment in the oxic cores. These results are similar to findings from studies in which cores containing fauna were compared to defaunated cores (e.g. Andersen \& Kristensen 1988, 1992). The study by Andersen \& Kristensen (1992) also found that macrofauna affected the transport of microalgae, initially deposited on the sediment surface, down to $3 \mathrm{~cm}$. In the present study elevated $\mathrm{PO}^{14} \mathrm{C}$ concentrations in the sediment were observed down to $7 \mathrm{~cm}$ depth. The more pronounced effect in the present study may be due to a longer experimental period, $80 \mathrm{~d}$ as opposed to $21 \mathrm{~d}$ in the study by Andersen \& Kristensen (1992). Different faunal composition may also contribute to the different degree of particle transport.

Factors other than oxygen may be important when decomposition under oxic and anoxic conditions is compared. For example, bioturbation was present in the oxic cores but not in the anoxic cores. However, Andersen \& Kristensen (1992) found that macrofauna had only a limited stimulating effect on $\mathrm{CO}_{2}$ release from the labile fraction of deposited fresh algae on the sediment surface, whereas they found a stimulation of $70 \%$ for $\mathrm{CO}_{2}$ release from the more refractory unlabeled organic matter in the sediment.

This study showed similar decomposition rates for organic matter under oxic and anoxic conditions when measured as loss of dissolved carbon compounds from POC. However, if complete mineralization to $\mathrm{CO}_{2}$ is considered, $25.2 \%$ more carbon was mineralized under oxic conditions. It is therefore important to distinguish between decomposition and mineralization.

Acknowledgements. The experimental work was carried out at the Department of Biology, University of Victoria, Canada, where Dr L. A. Hobson kindly provided laboratory space. This study was supported by a grant from the Danish Research Council for the Natural Sciences.

\section{LITERATURE CITED}

Andersen Fø, Hargrave BT (1984) Effects of Spartina detritus enrichment on exchange of nutrients between sediment and water in an intertidal area of Bay of Fundy. Mar Ecol Prog Ser 16:161-171

Andersen Fø, Kristensen E (1988) The influence of macrofauna on estuarine benthic community metabolism: a microcosm study. Mar Biol 99:591-603 
Andersen $F \varnothing$, Kristensen $E$ (1992) The importance of benthic macrofauna in decomposition of microalgae in a coastal marine sediment. Limnol Oceanogr 37:1392-1403

Anderson LG, Hall POJ, Iverfeldt $\AA$, Rutgers Van der Loeff MM, Sundby B, Westerlund SFG (1986) Benthic respiration measured by total carbonate production. Limnol Oceanogr 31:319-329

Benner R, MacCubbin AE, Hodson RE (1984) Anaerobic biodegradation of the lignin and polysaccharide components of lignocellulose and synthetic lignin by sediment microflora. Appl Environ Microbiol 47:998-1004

Canfield D (1989) Sulfate reduction and oxic respiration in marine sediments: implications for organic carbon preservation in euxinic environments. Deep Sea Res 36:121-138

Claypool GE, Kaplan IR (1974) The origin and distribution of methane in marine sediments. In: Kaplan IR (ed) Natural gases in marine sediments. Plenum Press, New York, $p$ 99-139

Fallon RD, Brock TD (1979) Decomposition of blue-green algal (cyanobacteria) blooms in Lake Mendota. Wisconsin. Appl Environ Microbiol 37:820-830

Foree EG, McCarty PL (1970) Anaerobic decomposition of algae. Environ Sci Technol 10:842-849

Guillard RRL, Ryther JH (1962) Studies of marine planktonic diatoms I. Cyclotella nana Hustedt, and Detonula confervacea (Cleve) Gran. Can J Microbiol 8:229-239

Hamilton SE, Hedges JI (1988) The comparative geochemistries of lignins and carbohydrates in an anoxic fjord. Geochim Cosmochim Acta 52:129-142

Hansen LS, Blackburn TH (1991) Aerobic and anaerobic mineralization of organic material in marine sediment microcosms. Mar Ecol Prog Ser 75:283-291

Hansen LS, Blackburn TH (1992) Mineralization budgets in sediment microcosms: effect of the infauna and anoxic conditions. FEMS Microbiol Ecol 102:33-43

Hargrave B (1972) Oxidation-reduction potentials, oxygen

This article was submitted to the editor concentration and oxygen uptake of profundal sediments in an eutrophic lake. Oikos 23:167-177

Henrichs SM, Doyle AP (1986) Decomposition of ${ }^{14} \mathrm{C}$-labeled organic substances in marine sediments. Limnol Oceanogr $31: 765-778$

Holland HD (1990) Origins of breathable air. Nature 347:17

Jorgensen BB, Fenchel T (1974) The sulfur cycle of a marine sediment model system. Mar Biol 24:184-201

Kepkay P, Andersen Fø (1985) Aerobic and anaerobic metabolism of a sediment enriched with Spartina detritus. Mar Ecol Prog Ser 21:153-161

Kristensen E, Andersen Fø, Blackburn TH (1992) Effects of benthic macrofauna and temperature on degradation of macroalgal detritus: the fate of organic carbon. Limnol Oceanogr 37:1404-1419

Kristensen E, Blackburn TH (1987) The fate of organic carbon and nitrogen in experimental marine sediment systems: influence of bioturbation and anoxia. J Mar Res 45:231-257

Otsuki A, Hanya T (1972) Production of dissolved organic matter from dead green algal cells II. Anaerobic microbial decomposition. Limnol Oceanogr 17:258-264

Parsons TR, Maita Y, Lalli CM (1984) A manual of chemical and biological methods for seawater analysis. Pergamon Press, Oxford

Parsons TR, Takahashi M, Hargrave B (1984) Biological oceanographic processes. Pergamon Press, Oxford

Reichardt W (1986) Enzymatic potential for decomposition of detrital biopolymers in sediments from Kiel Bay. Ophelia $26: 369-384$

Sancetta C, Calvert SE (1988) The annual cycle of sedimentation in Saanich Inlet, British Columbia: implications for the interpretation of diatom fossil assemblages. Deep Sea Res 35:71-90

Westrich JT, Berner RA (1984) The role of sedimentary organic matter in bacterial sulfate reduction: the $G$ model tested. Limnol Oceanogr 29:236-249

Manuscript first received: March 8, 1995

Revised version accepted: November 17, 1995 